\title{
WET OXIDATION OF DAIRY SEWAGE: THE KINETIC STUDY OF DECOMPOSITION OF THE MILK COMPONENTS
}

\author{
MOKRE UTLENIANIE ŚCIEKÓW MLECZARSKICH: \\ BADANIE KINETYKI ROZKŁADU SKŁADNIKÓW MLEKA
}

\begin{abstract}
The article presents the results of kinetic studies of the wet oxidation process of dairy sewage. The dairy sewage, obtained straight from the production line, was subjected to oxidation at $\mathrm{pH}$ close to the natural value of 7. Experiments were carried out in a stirred batch tank reactor at the oxygen partial pressure equal to $1 \mathrm{MPa}$ and at temperature ranging from 473 to $593 \mathrm{~K}$. The effectiveness of organic compounds decomposition was estimated based on the measurement of TOC. The kinetics of decomposition of milk components, ie lactose, protein and fat, as well as the kinetics of oxidation of intermediate products was the aim of the study. Measurement of the concentration of protein, fat and lactose was done with a milk composition analyzer, calibrated in relation to the dairy sewage. The obtained results were used to develop a mathematical model of wet oxidation of dairy sewage, including the group of analyzed compounds.
\end{abstract}

Keywords: wet oxidation, dairy sewage, kinetic model

Production of milk and milk products plays an important role in agriculture, food industry and food economy of many countries. In many of them more than $90 \%$ of the harvested milk is processed in dairy plants [1]. For several years a continuous increase of milk production has been observed in the world and it is expected that this trend will be maintained in the coming years [2]. With the increased production of milk and milk products, dairy industry will generate more process wastewater. Generally, the dairy industry is not considered to be harmful to the environment, because dairy pollutants are mainly of organic origin. However, new sewage treatment methods are being looked for as the ecological awareness and importance of improved standards of dairy sewage treatment grow. Dairy sewage is generated in two types of objects: milk collecting centers and dairy plants. The sewage differs according to the nature of production and type of final product. The sewage generated by milk collecting centers is mainly a diluted solution of milk, while sewage disposed of at dairy plants consists of the same compounds as milk, but in other

\footnotetext{
${ }^{1}$ Faculty of Process and Environmental Engineering, Lodz University of Technology, ul. Wólczańska 213, 90-924 Łódź, Poland, fax +48 426368133

*Corresponding author: klara.piotrowska@ wipos.p.lodz.pl
} 
proportions, which is shown in the Figure 1. Dairy sewage as well as milk consist of dissolved protein, from which $80 \%$ is casein, suspended fat containing predominantly short-chain fatty acid and carbohydrates consisting mainly of lactose [3].

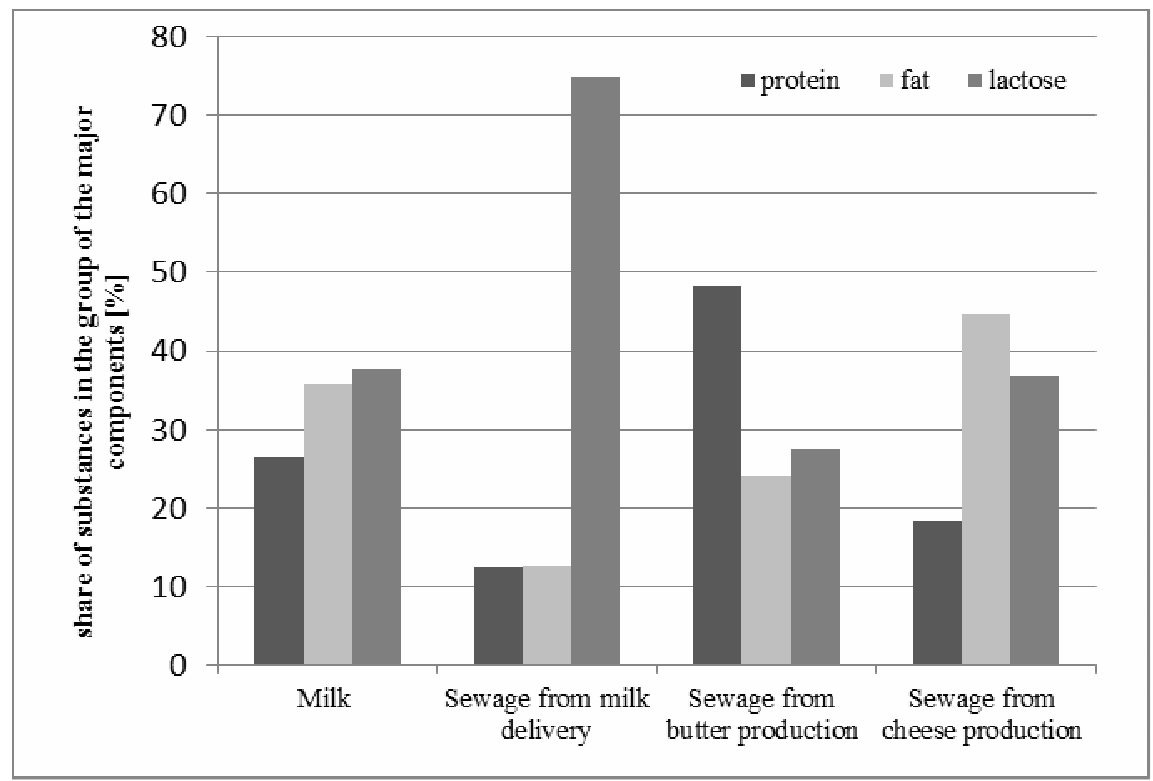

Fig. 1. The percentage of substances in major compounds (based on [4])

Untreated sewage, due to its composition and the presence of lactose, is very burdensome for receivers. Lactose quickly decomposes to other intermediate substances, such as organic acids, carbon dioxide and water. This, in turn leads to purification and decrease of $\mathrm{pH}$ value of the receiving water even below 2. A big load of organic compounds may also induce eutrophication caused by the expansion of water organisms, resulting in overgrowing of the water reservoir. These phenomena have their consequences - the receiving water becomes useless for municipal and industrial purposes.

Wet oxidation is a method of thermal treatment which leads to decomposition of organic and inorganic components dissolved or suspended in the aqueous phase. It is carried at high temperature ranging from 398 to $573 \mathrm{~K}$ and under high pressure of 0.5 to $20 \mathrm{MPa}$. In order to oxidize pollutants oxygen or air is introduced to the reaction medium. Pressure and temperature range used in the wet oxidation process significantly improves the method efficiency thanks to better solubility of oxygen at high temperatures and increased reaction rates. Wet oxidation process must be performed under elevated pressure, higher than water vapor pressure, in order to keep the solution in the aqueous phase. During the process organic compounds included in the solution are not decomposed completely, but they are converted into intermediate products which are usually less toxic and require less oxygen for their further degradation $[4,5]$.

Kinetic studies of the wet oxidation process cover mainly wet oxidation of sewage sludge from municipal wastewater treatment plants [6-9] as well as harmful and toxic 
organic compounds [10, 11]. For this type of processes several kinetic models were proposed and their quality was evaluated experimentally [12]. References to wet oxidation of pollutants contained in the dairy sewage can hardly be found in the technical literature. Results of a similar research were presented by Chia et al [13] who conducted the experiments using lactose solution at 423 to $443 \mathrm{~K}$ and pressure about $0.7 \mathrm{MPa}$ in the presence of $\mathrm{Pt} / \mathrm{Al}_{2} \mathrm{O}_{3}, \mathrm{CeMn}$ and $\mathrm{Pt} / \mathrm{CeMn}$ catalysts in order to find an alternative method for treatment of cheese production sewage. Much more attention was paid to the catalytic decomposition of lactose to an intermediate product - lactobionic acid, which is a commercial product [14-16]. In the case of dairy sewage such a solution cannot exist due to the presence of other substances.

In this study, dairy sewage was subjected to wet oxidation and the results of research were used to create a kinetic model of the reaction and to determine its parameters.

\section{Experimental}

The experimental material was taken from a dairy plant which manufactures products on the basis of still improved production techniques and technologies.

The dairy plant specializes in the production of fresh milk, cream, cottage cheese, cheese, kefir, buttermilk and butter. Sewage samples for the experiments were taken directly from the production process. Average parameters of the sewage subjected to analysis are given in Table 1.

Table 1

The average parameters of sewage subjected to wet oxidation

\begin{tabular}{|c|c|c|}
\hline Parameter & Unit & Value \\
\hline TOC & {$\left[\mathrm{mg} \cdot \mathrm{dm}^{-3}\right]$} & 1090 \\
\hline Protein & {$\left[\mathrm{mg} \cdot \mathrm{dm}^{-3}\right]$} & 162.9 \\
\hline Fat & {$\left[\mathrm{mg} \cdot \mathrm{dm}^{-3}\right]$} & 52.6 \\
\hline Lactose & {$\left[\mathrm{mg} \cdot \mathrm{dm}^{-3}\right]$} & 37.04 \\
\hline $\mathrm{pH}$ & - & 6.98 \\
\hline
\end{tabular}

The wet oxidation process of dairy sewage was conducted in a laboratory batch wellmixed, high pressure, titanium reactor. The experimental procedure of wet oxidation was described in detail in the previous publication [16]. Figure 2 shows a diagram of the apparatus.

The process was conducted under partial pressure of oxygen equal to $1 \mathrm{MPa}$ at process temperature 453, 473, 493, 503 and $523 \mathrm{~K}$. Sewage sample of the reaction mixture was taken at 120, 240, 360, 480, 600, 900, 1800 and $3600 \mathrm{~s}$ after starting the process, ie when the oxygen was injected into the reactor. Detailed description of experimental procedure was published at [17]. Total organic carbon concentration was determined using the coulometric method which also was described in detail in our previous publication [17].

Lactose, protein and fat concentrations were measured with a LactoStar milk composition analyzer (Gerber). Before the measurement, this analyzer was calibrated in relation to dairy sewage. The concentration of protein in a sewage sample used to calibrate the apparatus, was determined based on the measurement of Kjeldahl nitrogen. The fat concentration was determined on the basis of the measurement of ether extract. Both measurements were made on the basis of standardization procedures. The milk composition 
analyzer was functioning on the basis of measurements in the two systems: a thermoanalytical measuring system and turbidimetry conductivity system.

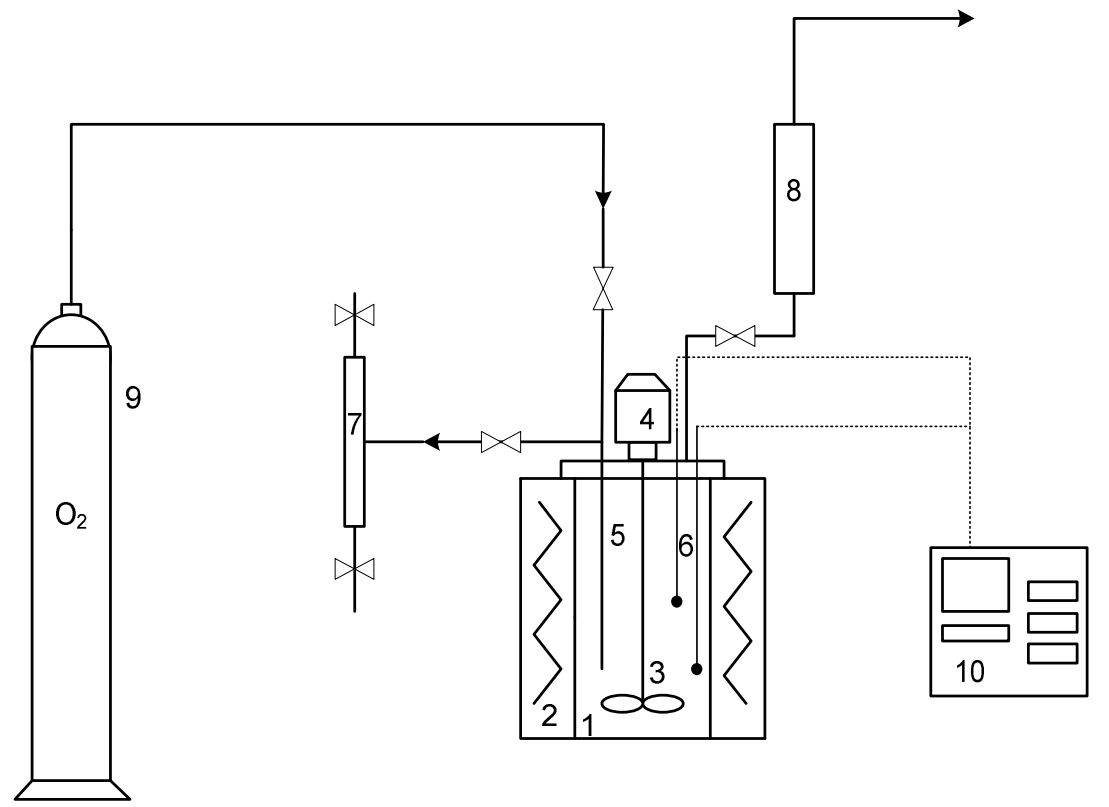

Fig. 2. Diagram of the experimental reactor: 1 - reactor, 2 - heating jacket, 3 - stirrer, 4 - motor of the stirrer, 5 - gas inlet/sample collection, 6 - temperature and pressure meters, 7 - water-cooled sampler, 8 - cooler, 9 - oxygen cylinder, 10 - control and measuring system

\section{Results}

The experiments show the effect of process temperature on the degree of decomposition of organic compounds contained in dairy sewage to $\mathrm{CO}_{2}$ and $\mathrm{H}_{2} \mathrm{O}$. The results of wet oxidation process are shown in Table 2 and Figure 3.

Changes in relative concentrations of organic carbon in the samples taken during wet oxidation of dairy sewage $\left(\mathrm{TOC} / \mathrm{TOC}_{0}\right)$

\begin{tabular}{|c|c|c|c|c|c|c|c|c|c|c|}
\hline \multirow{2}{*}{ No. } & Temperature & \multicolumn{9}{|c|}{ Time $[\mathbf{s}]$} \\
\cline { 3 - 11 } & {$[\mathbf{K}]$} & $\mathbf{0}$ & $\mathbf{1 2 0}$ & $\mathbf{2 4 0}$ & $\mathbf{3 6 0}$ & $\mathbf{4 8 0}$ & $\mathbf{6 0 0}$ & $\mathbf{9 0 0}$ & $\mathbf{1 8 0 0}$ & $\mathbf{3 6 0 0}$ \\
\hline 1 & 453 & 1.000 & 0.906 & 0.892 & 0.829 & 0.813 & 0.798 & 0.801 & 0.793 & 0.798 \\
\hline 2 & 473 & 1.000 & 0.874 & 0.804 & 0.780 & 0.764 & 0.761 & 0.740 & 0.736 & 0.710 \\
\hline 3 & 493 & 1.000 & 0.752 & 0.691 & 0.673 & 0.620 & 0.610 & 0.605 & 0.606 & 0.566 \\
\hline 4 & 503 & 1.000 & 0.688 & 0.599 & 0.586 & 0.560 & 0.567 & 0.530 & 0.508 & 0.444 \\
\hline 5 & 523 & 1.000 & 0.595 & 0.552 & 0.525 & 0.516 & 0.494 & 0.439 & 0.393 & 0.335 \\
\hline
\end{tabular}

From the data shown in Figure 3 it follows that the process temperature has a significant effect on the decomposition. At the temperature $453 \mathrm{~K}$, the decrease of TOC in 
the reaction mixture is in the range of about $20 \%$ in relation to the initial value. Elevation of the process temperature to $523 \mathrm{~K}$ increases the degree of TOC nearly to $70 \%$.

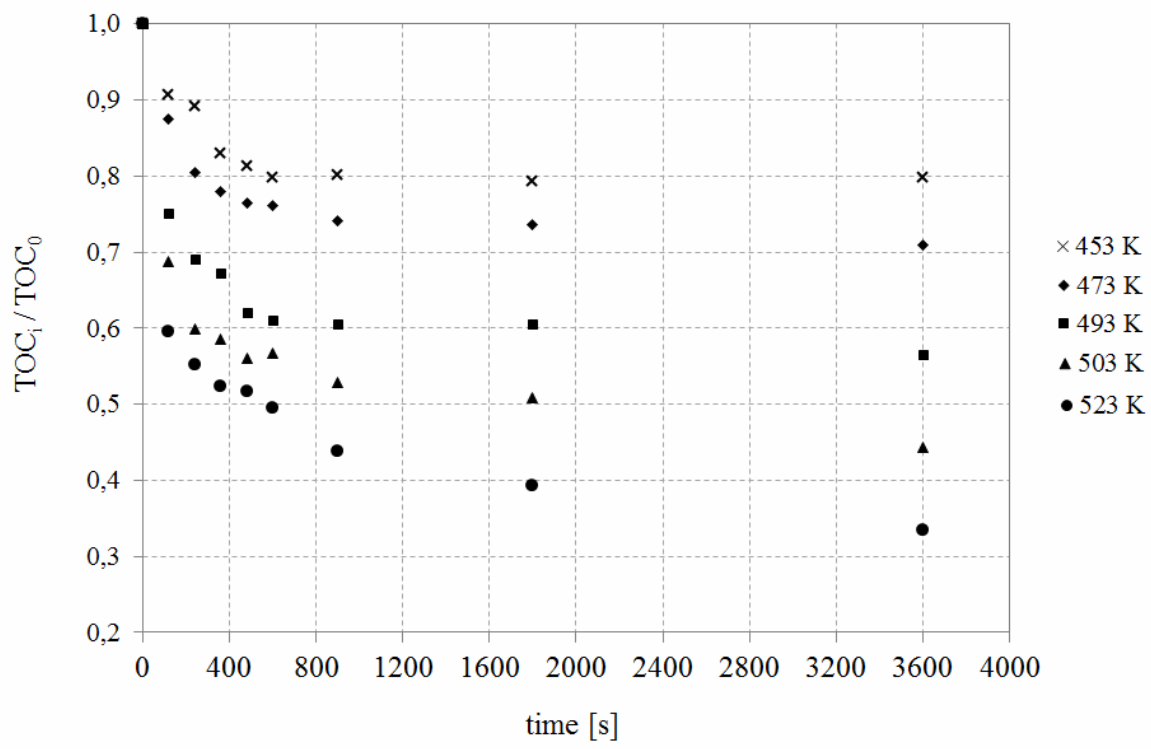

Fig. 3. Changes in relative concentrations of organic carbon in the samples taken during wet oxidation of dairy sewage $\left.\left(\mathrm{TOC}_{\mathrm{TOC}}\right)\right)$

Later in this article, the following abbreviations are used: $\mathrm{A} \equiv$ lactose, $\mathrm{B} \equiv$ protein, $\mathrm{C} \equiv$ fat, $\mathrm{D} \equiv$ organic intermediate compounds (IOC), $\mathrm{E} \equiv$ inorganic compounds $\left(\mathrm{CO}_{2}\right)$.

The data used to developing the kinetic model of milk components oxidation are presented below. Tables 3, 4 and 5 show changes in relative concentration of lactose, protein and fat during the wet oxidation process, respectively.

Changes in relative concentrations of lactose in the samples

Table 3 taken during wet oxidation of dairy sewage $\left(C_{A} / C_{A 0}\right)$

\begin{tabular}{|c|c|c|c|c|c|c|c|c|c|c|}
\hline \multirow{2}{*}{ No. } & Temperature & \multicolumn{9}{|c|}{ Time $[\mathbf{s}]$} \\
\cline { 3 - 11 } & {$[\mathbf{K}]$} & $\mathbf{0}$ & $\mathbf{1 2 0}$ & $\mathbf{2 4 0}$ & $\mathbf{3 6 0}$ & $\mathbf{4 8 0}$ & $\mathbf{6 0 0}$ & $\mathbf{9 0 0}$ & $\mathbf{1 8 0 0}$ & $\mathbf{3 6 0 0}$ \\
\hline 1 & 453 & 1.000 & 0.497 & 0.375 & 0.154 & 0.131 & 0.109 & 0.120 & $<\mathrm{LOQ}$ & $<\mathrm{LOQ}$ \\
\hline 2 & 473 & 1.000 & 0.449 & 0.377 & 0.306 & 0.176 & 0.117 & 0.093 & $<\mathrm{LOQ}$ & $<\mathrm{LOQ}$ \\
\hline 3 & 493 & 1.000 & 0.420 & 0.245 & 0.186 & 0.174 & 0.139 & 0.104 & $<\mathrm{LOQ}$ & $<\mathrm{LOQ}$ \\
\hline 4 & 503 & 1.000 & 0.398 & 0.220 & 0.121 & 0.099 & 0.098 & 0.076 & $<\mathrm{LOQ}$ & $<\mathrm{LOQ}$ \\
\hline 5 & 523 & 1.000 & 0.389 & 0.222 & 0.122 & 0.088 & 0.077 & 0.055 & $<\mathrm{LOQ}$ & $<\mathrm{LOQ}$ \\
\hline
\end{tabular}

From these data it follows that the concentration of initial compounds in milk is reduced significantly in the first minutes of the process. 
Changes in relative concentrations of protein in the samples taken during wet oxidation of dairy sewage $\left(C_{B} / C_{B 0}\right)$

\begin{tabular}{|c|c|c|c|c|c|c|c|c|c|c|}
\hline \multirow{2}{*}{ No. } & Temperature & \multicolumn{10}{|c|}{ Time $[\mathbf{s}]$} \\
\cline { 3 - 12 } & {$[\mathbf{K}]$} & $\mathbf{0}$ & $\mathbf{1 2 0}$ & $\mathbf{2 4 0}$ & $\mathbf{3 6 0}$ & $\mathbf{4 8 0}$ & $\mathbf{6 0 0}$ & $\mathbf{9 0 0}$ & $\mathbf{1 8 0 0}$ & $\mathbf{3 6 0 0}$ \\
\hline 1 & 453 & 1.000 & 0.445 & 0.349 & 0.286 & 0.254 & 0.222 & 0.127 & $<\mathrm{LOQ}$ & $<\mathrm{LOQ}$ \\
\hline 2 & 473 & 1.000 & 0.444 & 0.349 & 0.317 & 0.285 & 0.190 & 0.063 & $<\mathrm{LOQ}$ & $<\mathrm{LOQ}$ \\
\hline 3 & 493 & 1.000 & 0.341 & 0.239 & 0.205 & 0.171 & 0.136 & 0.034 & $<\mathrm{LOQ}$ & $<\mathrm{LOQ}$ \\
\hline 4 & 503 & 1.000 & 0.369 & 0.246 & 0.185 & 0.185 & 0.092 & 0.031 & $<\mathrm{LOQ}$ & $<\mathrm{LOQ}$ \\
\hline 5 & 523 & 1.000 & 0.283 & 0.220 & 0.188 & 0.157 & 0.094 & 0.031 & $<\mathrm{LOQ}$ & $<\mathrm{LOQ}$ \\
\hline
\end{tabular}

Changes in relative concentrations of fat in the samples

Table 5 taken during wet oxidation of dairy sewage $\left(C_{C} / C_{C 0}\right)$

\begin{tabular}{|c|c|c|c|c|c|c|c|c|c|c|}
\hline \multirow{2}{*}{ No. } & Temperature & \multicolumn{9}{|c|}{ Time $[\mathbf{s}]$} \\
\cline { 3 - 12 } & {$[\mathbf{K}]$} & $\mathbf{0}$ & $\mathbf{1 2 0}$ & $\mathbf{2 4 0}$ & $\mathbf{3 6 0}$ & $\mathbf{4 8 0}$ & $\mathbf{6 0 0}$ & $\mathbf{9 0 0}$ & $\mathbf{1 8 0 0}$ & $\mathbf{3 6 0 0}$ \\
\hline 1 & 453 & 1.000 & 0.750 & 0.500 & 0.500 & 0.375 & 0.375 & $<\mathrm{LOQ}$ & $<\mathrm{LOQ}$ & $<\mathrm{LOQ}$ \\
\hline 2 & 473 & 1.000 & 0.875 & 0.750 & 0.625 & 0.500 & 0.500 & $<\mathrm{LOQ}$ & $<\mathrm{LOQ}$ & $<\mathrm{LOQ}$ \\
\hline 3 & 493 & 1.000 & 0.857 & 0.429 & 0.286 & 0.286 & 0.143 & $<\mathrm{LOQ}$ & $<\mathrm{LOQ}$ & $<\mathrm{LOQ}$ \\
\hline 4 & 503 & 1.000 & 0.750 & 0.500 & 0.375 & 0.375 & 0.250 & $<\mathrm{LOQ}$ & $<\mathrm{LOQ}$ & $<\mathrm{LOQ}$ \\
\hline 5 & 523 & 1.000 & 0.667 & 0.500 & 0.500 & 0.333 & 0.167 & $<\mathrm{LOQ}$ & $<\mathrm{LOQ}$ & $<\mathrm{LOQ}$ \\
\hline
\end{tabular}

\section{Kinetic model}

Based on the experimental results it was found that organic compounds in the sewage were converted to intermediate products containing TOC and next to $\mathrm{CO}_{2}$ and $\mathrm{H}_{2} \mathrm{O}$. On this basis, the following scheme of wet oxidation process was proposed (Fig. 4):

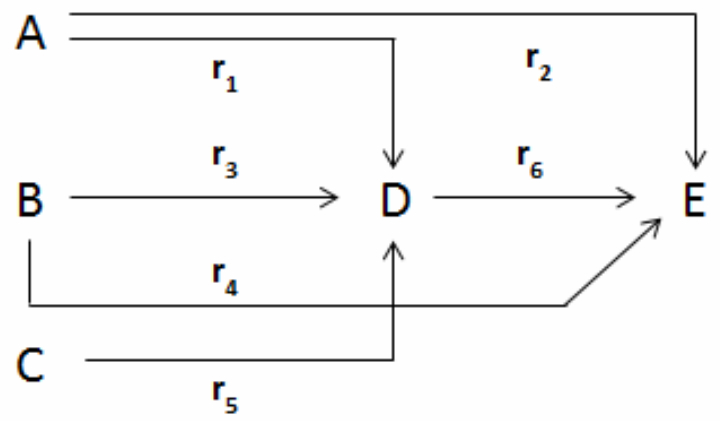

Fig. 4. The proposed scheme of dairy sewage oxidation: A - lactose, B - proteins, C - fat, D - organic intermediate compounds (IOC), E - inorganic compounds $\left(\mathrm{CO}_{2}\right)$

The above scheme of dairy sewage oxidation and the obtained experimental data were used in a mathematical description of the process in a batch tank reactor with perfect stirring. It was assumed that each reaction was of the second order (Fig. 4). Hence, their rates are described by the following equations:

$$
r_{1}=k_{1} C_{A}^{2}
$$




$$
\begin{aligned}
& r_{2}=k_{2} C_{A}^{2} \\
& r_{3}=k_{3} C_{B}^{2} \\
& r_{4}=k_{4} C_{B}^{2} \\
& r_{5}=k_{51} C_{C}^{2} \\
& r_{6}=k_{6} C_{C}^{2}
\end{aligned}
$$

where:

$$
k_{i}=k_{i 0} \cdot \exp \left(-\frac{E}{R \cdot T}\right), i=1 \ldots 6
$$

The mass balance for each reactant of the liquid phase has the form:

$$
\begin{gathered}
\frac{d C_{A}}{d t}=-k_{1} C_{A}^{2}-k_{2} C_{A}^{2}=-\left(k_{1}+k_{2}\right) C_{A}^{2}, C_{A}(0)=C_{A 0} \\
\frac{d C_{B}}{d t}=-k_{3} C_{B}^{2}-k_{4} C_{B}^{2}=-\left(k_{3}+k_{4}\right) C_{B}^{2}, C_{B}(0)=C_{B 0} \\
\frac{d C_{C}}{d t}=-k_{5} C_{C}^{2}, C_{C}(0)=C_{C 0} \\
\frac{d C_{D}}{d t}=k_{1} C_{A}^{2}+k_{3} C_{B}^{2}+k_{5} C_{C}^{2}-k_{6} C_{D}^{2}, C_{D}(0)=C_{D 0} \\
\frac{d C_{E}}{d t}=k_{2} C_{A}^{2}+k_{4} C_{B}^{2}+k_{6} C_{D}^{2}, C_{E}(0)=C_{E 0}
\end{gathered}
$$

Differential equations (8)-(12) are the mathematical description of the process of wet oxidation of diary sewage in the experimental reactor.

Based on the data obtained from laboratory experiments, unknown parameters of the kinetic equations described by equations (1)-(7) can be identified.

The estimation of kinetic parameters consists in selecting them in such a way that the concentration profiles obtained experimentally and by analytical analysis remain in the best agreement possible. A quantitative measure of agreement of the two distributions is the so called quality index, which was defined as the sum of square deviations of concentrations determined experimentally and obtained from state equations of the process performed in a given chemical reactor type:

$$
I(\mathbf{p})=\sum_{l=1}^{n T} \sum_{j=1}^{n t} \sum_{i=1}^{n c}\left(C_{i, j, l}^{\exp }-C_{i, j, l}\right)^{2}
$$

where $\mathbf{p}$ is the vector of kinetic parameters for reaction (1) to (6):

$$
\mathbf{p}=\left[k_{01}, E_{A 1}, k_{02}, E_{A 2}, \ldots, k_{06}, E_{A 6}\right]^{T}
$$

and $n T, n t, n c$ are the number of the number of temperature, moments of sampling and reagents used in experiments. 
In the assumed quality index $I(\mathbf{p})$, the summing procedure includes the following factors: the temperature, moments in which the measurements was taken and reagents present in reaction mixture. At such a criterion of fitting, the estimation parameters in equations (1)-(7) will be limited to looking for a mapping minimum (13). A minimum of the quality index was searched using Marquardt's iterative method [18]. In this method, differential equations (8)-(12) with the initial conditions were solved using Merson's method [19]. Table 6 gives the values of kinetic parameters that minimize the quality index (13).

Table 6

Parameters of the reaction kinetic model

\begin{tabular}{|c|c|c|}
\hline \multirow{2}{*}{ Reaction number } & Pre-potential factor & Activation energy \\
\cline { 2 - 3 } & {$\left[\mathbf{m}^{\mathbf{3}} \cdot \mathbf{m o l}^{\mathbf{- 1}} \cdot \mathbf{s}^{\mathbf{- 1}}\right]$} & {$\left[\mathbf{J} \cdot \mathbf{m o l}^{\mathbf{- 1}} \cdot \mathbf{K}^{\mathbf{- 1}}\right]$} \\
\hline 1 & $1.551 \cdot 10^{-3}$ & $3.099 \cdot 10^{3}$ \\
\hline 2 & $9.106 \cdot 10^{6}$ & $9.248 \cdot 10^{4}$ \\
\hline 3 & $6.539 \cdot 10^{-4}$ & $2.506 \cdot 10^{3}$ \\
\hline 4 & $1.678 \cdot 10^{3}$ & $5.239 \cdot 10^{4}$ \\
\hline 5 & $8.565 \cdot 10^{-3}$ & $1.598 \cdot 10^{3}$ \\
\hline 6 & $7.214 \cdot 10^{3}$ & $8.216 \cdot 10^{4}$ \\
\hline
\end{tabular}

A comparison of experimental results and results calculated using the proposed kinetic model for chosen temperature (453 and $523 \mathrm{~K}$ ) is illustrated in Figure 5.
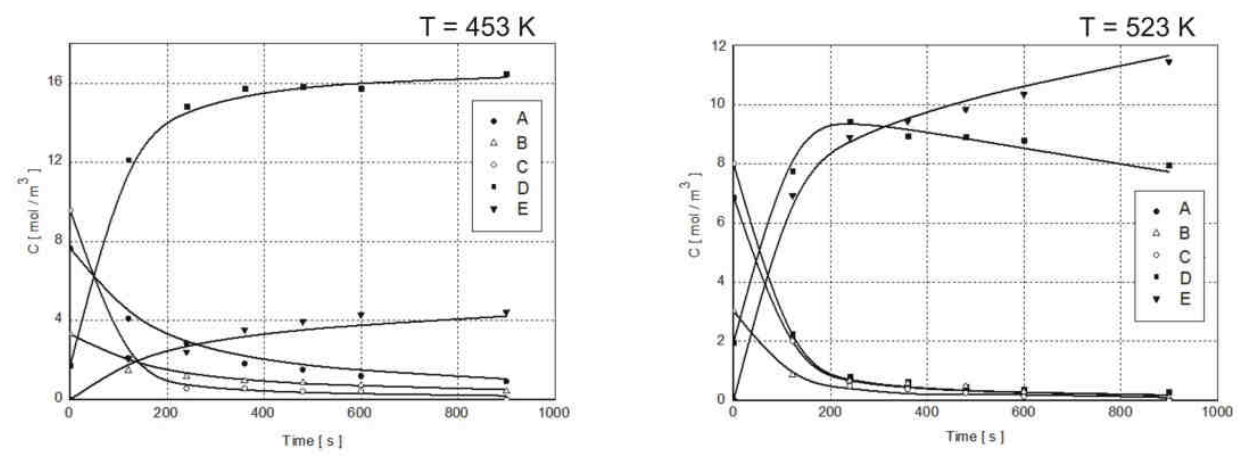

Fig. 5. A comparison of experimental results and results obtained from proposed kinetic model of milk components oxidation for temperature equal 453 and $523 \mathrm{~K}$ (A - lactose, B - protein, C - fat, $\mathrm{D}$ - organic intermediate compounds, $\mathrm{E}-\mathrm{CO}_{2}$ )

To validate the results of estimation of kinetic model parameters, Figure 6 shows a parity plot for experimental TOC concentrations and those concentrations predicted by the proposed kinetic model defined by the equations (1)-(12).

The obtained results show good agreement of both types of results; correlation coefficient between variables presented on the Figure 6 is $R^{2}=0.985$. Discrepancies between calculated results and values of TOC concentration measured in the samples are a result of unavoidable measuring errors. However, the statistical analysis of results confirms that the model described by equations (1) to (12) along with the values of kinetic parameters given in Table 6, provides an adequate description of changes in the 
concentration of reaction mixture components during the wet oxidation of dairy sewage in temperature range $423-563 \mathrm{~K}$ and at partial pressure of oxygen equal to $1 \mathrm{MPa}$.

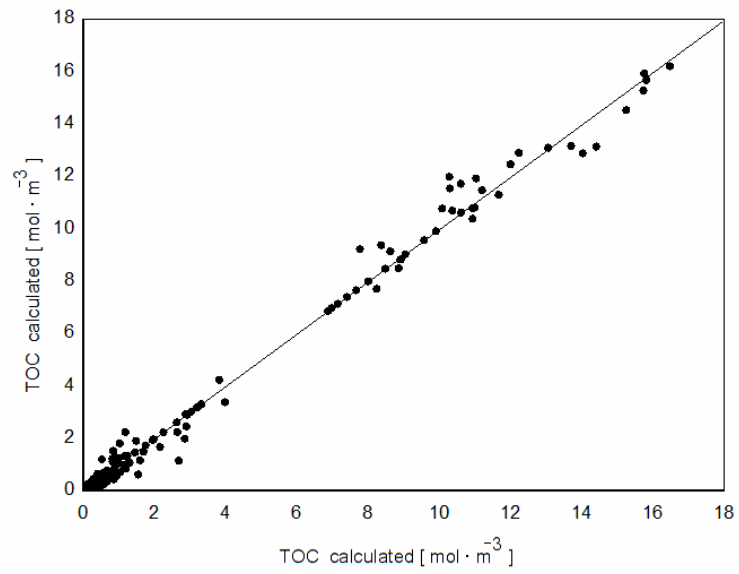

Fig. 6. Fitting the calculated TOC concentration to experimental data

\section{Conclusions}

The experimental results show that organic compounds contained in dairy sewage are resistant to the decomposition to carbon dioxide and water. However, they are converted to other organic substances. The highest degree of TOC reduction of sewage was about $70 \%$ at $523 \mathrm{~K}$, under the partial pressure of $\mathrm{O}_{2}$ equal to $1 \mathrm{MPa}$. Rising process temperature caused an increase in TOC reduction, so that further increase could result in an overall reduction of organic compounds in the sewage. A kinetic model of wet oxidation process was proposed and its kinetic parameters were determined based on experimental data. The results of the proposed model show good agreement with experimental data.

\section{Nomenclature}

$\begin{array}{ll}\text { A, B, C, D, E } & \text { - reagents } \\ C & \text { - molar concentration }\left[\mathrm{mol} \cdot \mathrm{m}^{-3}\right] \\ E & \text { - activation energy }\left[\mathrm{J} \cdot \mathrm{mol}^{-1}\right] \\ k & \text { - reaction rate constant }\left[\mathrm{s}^{-1}\right] \\ P_{O 2} & \text { - partial pressure of oxygen }[\mathrm{MPa}] \\ \mathbf{p} & \text { - vector of kinetic parameters } \\ r & \text { - reaction rate }\left[\mathrm{mol} \cdot \mathrm{m}^{-3} \cdot \mathrm{s}^{-1}\right] \\ R & \text { - universal gas constant }\left[\mathrm{J} \cdot \mathrm{mol}^{-1} \cdot \mathrm{K}^{-1}\right] \\ t & \text { - time }[\mathrm{s}] \\ T & \text { - temperature }[\mathrm{K}] \\ \text { TOC } & \text { - total organic carbon }\left[\mathrm{mol} \mathrm{C} \cdot \mathrm{m}^{-3}\right],\left[\mathrm{mg} \cdot \mathrm{dm}^{-3}\right]\end{array}$




\section{Indexes}

0 - initial conditions

A, B, C, D, E - refer to reagents

$\mathrm{t} \quad-$ refers to measurement time

$\mathrm{T} \quad-$ refers to process temperature

c - refers to compound

\section{Acknowledgements}

This work was done in the frame of NN 523450536 project financed by the Polish Ministry of Science and Higher Education.

\section{References}

[1] Parzonko A. The state and the tendencies of changes in production of milk in the world, Annals of Agricult Sci - Series G. 2009;96(1):16-26.

[2] International Dairy Federation: Bulletin of the International Dairy Federation 446/2010, 2010.

[3] Wattiaux MA. Milk Composition and Nutritional Value, Dairy Essentials, Chapter 19, The Babcock Institute for International Dairy Research and Development 2011.

[4] Kolaczkowski ST, Plucinski P, Beltran FJ, Rivas FJ, McLurgh DB. Wet air oxidation: a review of process technologies and aspects in reactor design. Chem Eng J. 1999;73:143-160. DOI: 10.1016/S1385-8947(99)00022-4.

[5] Bhargava SK, Tardio J, Prasad J, Föger K, Akolekar DB, Grocott ST. Wet oxidation and catalytic wet oxidation. Ind Eng Chem Res. 2006;45(4):1221-1258. DOI: 10.1021/ie051059n.

[6] Khan Y, Anderson GK, Elliott DJ. Wet oxidation of activated sludge. Water Res. 1999;33(7):1681-1687. DOI: 10.1016/S0043-1354(98)00387-X.

[7] Genc N, Yonsel S, Dagasan L, Onar AN. Wet oxidation: a pre-treatment procedure for sludge. Waste Manage. 2002;22(6):611-6. DOI: 10.1016/S0956-053X(02)00040-5.

[8] Mucha J, Zarzycki R. Analysis of wet oxidation process after initial thermohydrolysis of excess sewage sludge. Water Res. 2008;42:3025-3032. DOI: 10.1016/j.watres.2007.11.012.

[9] Imbierowicz M, Chacuk A. The advanced kinetic model of the excess activated sludge wet oxidation. Polish J Chem Technol. 2006;8(2):16-19.

[10] Suárez-Ojeda ME, Metcalfe IS, Font J, Carrera J. Calibration of a kinetic model for wet air oxidation (WAO) of substituted phenols: Influence of experimental data on model prediction and practical identifiability. Chem Eng J. 2009;150:328-336. DOI: 10.1016/j.cej.2009.01.006.

[11] García-Molina V, Kallas J, Esplugas S. Wet oxidation of 4-chlorophenol: Kinetic study. Chem Eng J. 2007;126(1):59-65. DOI: 10.1016/j.cej.

[12] Li L, Chen P, Gloyna EF. Generalized kinetic model for wet oxidation of organic compounds. AIChE J. 1991;37(11):1687-1697. DOI: 10.1002/aic.690371112.

[13] Chia YN, Latusek MP, Holles JH. Catalytic wet oxidation of lactose. Ind Eng Chem Res. 2008;47(12):40494055. DOI: $10.1021 / \mathrm{ie} 701779 \mathrm{u}$.

[14] Murzina EV, Tokarev AV, Korda’s K, Karhu H, Jyri-Pekka M, Murzin DY. D-lactose oxidation over gold catalysts. Catal Today. 2008;131:385-392. DOI: 10.1016/j.cattod.2007.10.080.

[15] Patrick A, Abraham M. Evaluation of a monolith-supported $\mathrm{Pt}^{-} \mathrm{Al}_{2} \mathrm{O}_{3}$ catalyst for wet oxidation of carbohydrate-containing waste streams. Environ Sci Technol. 2000;34:3480-3488. DOI: $10.1021 / \mathrm{es} 000887 \mathrm{z}$.

[16] Hendriks HEJ, Kuster BFM, Marin GB. The effect of bismuth on the selective oxidation of lactose on supported palladium catalysts. Carbohydr Res. 1990;204:121-129. DOI: 10.1016/0008-6215(90)84027-R.

[17] Piotrowska K, Imbierowicz M, Chacuk A. Wet oxidation of dairy sewage. Ecol Chem Eng S. 2012;19(1):29-38. DOI: 10.2478/v10216-011-0003-1.

[18] Marquardt D. An algorithm for least-squares estimation of nonlinear parameters. SIAM J Appl Math. 1963;11:431-441.

[19] Christiansen J. Numerical solution of ordinary differential equations of the $1^{\text {st }}$ order using a method for automatic step change. Numer Math. 1970;14:317. 


\title{
MOKRE UTLENIANIE ŚCIEKÓW MLECZARSKICH: BADANIE KINETYKI ROZKŁADU SKŁADNIKÓW MLEKA
}

\author{
Wydział Inżynierii Procesowej i Ochrony Środowiska, Politechnika Łódzka
}

\begin{abstract}
Abstrakt: Artykuł prezentuje wyniki badań kinetycznych procesu mokrego utleniania ścieków pochodzących z przemysłu mleczarskiego. Utlenianiu poddane zostały ścieki mleczarskie o ich naturalnym $\mathrm{pH}$ zbliżonym do wartości 7, pobrane bezpośrednio po procesie produkcyjnym. Badania prowadzone były w okresowym reaktorze zbiornikowym z mieszadłem, przy ciśnieniu cząstkowym tlenu wynoszącym $1 \mathrm{MPa}$, w zakresie zmienności temperatury od 473 do $593 \mathrm{~K}$. Oceny efektywności stopnia rozkładu związków organicznych dokonano na podstawie pomiaru wartości TOC. Celem badań było zbadanie kinetyki rozkładu związków wchodzących w skład mleka - laktozy, białek i tłuszczu oraz kinetyki przemian produktów pośrednich utleniania - lotnych kwasów tłuszczowych. Pomiar stężenia białek, tłuszczu i laktozy odbywał się z wykorzystaniem analizatora składu mleka, skalibrowanego w stosunku do ścieków mleczarskich. Otrzymane wyniki posłużyły do budowy modelu matematycznego procesu mokrego utleniania ścieków, obejmującego grupy analizowanych związków.
\end{abstract}

Słowa kluczowe: mokre utlenianie, ścieki mleczarskie, model kinetyczny 